BIORHEOLOGY, 28; 599, 1991

$0006-355 X / 91 \$ 3.00+.00$ Printed in the USA

Copyright (c) 1992 Pergamon Press plc. All rights reserved.

\title{
CONTENTS OF CLINICAL HEMORHEOLOGY, VOLUME 11, NUMBERS 1/2
}

CONTENTS

G. Caimi, A. Serra, R. Lo Presti,

S. D'Asaro B. Canino, and A. Sarno

F. Nobili, S. Bertolini, N. Elicio

S. Francione, S. Marenco, G. Rodriguez,

U. Tortorolo, P.A. Viale, and G. Rosadini

O.K. Başkurt, E. Levi and S.O. Andaç

H.-Q. Chen, L.-N. Yan, L. Li, G.-H. Zhong and H.-G. Wu

P. Falke, F. Lindgärde, and L. Stavenow

G. Buonocore, S. Berni, D. Gioia

G. Garosi, and R. Bracci

G. Caimi, A. Serra, F. Vaccaro, R. Lo Presti, G. Grifo, S. D'Asaro, F.P. Picone and A. Sarno

R. Guillet, B. Nalpas, P. Perrotin,

Y. Beuzard, D. Koutsouris, and M. Boynard

H.R. Arntz, G. Roll, J. Heitz, J.H. Schäfer and R. Schröder

F. Kooshesh, S.-A. Evans, J.G. Jones

and C.A.J. Wardrop

H. Hiruma, M. Ito, H. Shio,

and N. Uyesaka

E. Ernst, K.L. Resch, Ch. Schmidlechner,

H.F. Paulsen, and T. Saradeth

J.-C. Zhu, P.C.W. Stone, and J. Stuart

O.K. Başkurt, E. Levi, S. Çağlayan, N. Dikmenoğlu, O. Üçer, R. Güner, and S. Yörükan

E. Ernst and M. Marschall

A. Vayà, M. Martinez, and J. Aznar

P. Whittingstall

Papers

1 Diabetic retinopathy: Monitoring of the macro and microrheological parameters after oral administration of a single dose of calcium dobesilate (Doxium ${ }^{\circledR}$ )

9 Hemorheological and cerebral blood flow changes induced by LDL-apheresis in familial hypercholesterolemic patients

19 Hemorheologic effects of reticulocytosis

25 Alteration in viscoelasticity of whole blood from dogs with experimental acute necrotizing pancreatitis

35 Differences in blood viscosity, glycosylated hemoglobin and platelet count between male patients with carotid territory transient ischemic attacks and minor strokes

41 Whole blood filterability in the neonate

49 Erythrocyte $\mathrm{Ca}^{2+}$ content and red cell membrane transverse fluidity gradient in a group of subjects with chronic renal failure (CRF)

55 Increased erythrocyte rigidity in chronic alcoholics without cirrhosis: Deformability improvement of erythrocyte sub-populations after alcohol withdrawal

63 Effects of different thrombolytic agents on blood rheology in acute myocardial infarction

79 Filterability of leukocytes in purified suspensions and in diluted whole blood

91 Effect of contrast media on RBC filterability studied with nickel mesh filtration

107 n-3 fatty acids reduce blood viscosity in hyperlipoproteinemia: Results of a double blind study

113 Rheological control preparations for tests of erythrocyte filterability

121 The role of hemorheologic factors in the coronary circulation

Brief Communication

129 Reduced leukocyte filterability after acute physical stress

Letters to the Editors-in-Chief

133 Erythrocyte deformability in patients with an ischemic pathology

137 Comments on Myrenne Aggregometer operational modes

141 Contents of Biorheology, Volume 27, Number 5 